Brit. J. industr. Med., 1951, 8, 74.

\title{
THE ACTION OF ANTHRACITE AND BITUMINOUS COAL DUSTS MIXED WITH QUARTZ ON THE LUNGS OF RATS
}

\author{
BY \\ S. C. RAY, E. J. KING, and C V. HARRISON \\ From the Postgraduate Medical School, London \\ (RECEIVED FOR PUBLICATION OCTOBER 26, 1950)
}

Belt and King (1945) studied the tissue reactions produced in animals by selected dusts from South Wales coal mines, and found that clean coal (low ash coal fraction containing $99 \%$ coal) produced only minimal fibrosis (grade 1) with simple foreign body reaction in 250 to 500 days. In experiments with high ash coal fractions which contained from 37 to $66 \%$ coal and about 1 to $3 \%$ quartz; the rest being kaolin and mica, grade 1 fibrosis was also produced in 250 days; and the reticulin was slightly denser in character, although it could not be classified as grade 2 fibrosis. In their experiments with airborne dusts, they examined 14 samples from six different mines, which included anthracite mines with both a high and low incidence of silicosis, and also steam coal and bituminous coal mines. Nine of these samples produced only a simple foreign body reaction with grade 1 fibrosis, the average coal content of these nine samples being $85 \%$, and the average siliceous mineral content $13 \%$. The remaining five samples produced something more than a foreign body reaction, and fibrosis was of grades 2 and 3 . These dusts averaged $74 \%$ of coal and contained $39,28,14,17$, and $15 \%$ (average $22 \%$ ) of siliceous minerals, there being a considerable overlap between the two groups.

Further studies were made using artificial mixtures of airborne mine dusts with amounts of pure quartz which were varied from 19 to $28 \%$, and in one case made as high as $51 \%$. In all these experiments, at the end of one year, the fibrosis was of grade 4 type, and no difference could be found between anthracite and bituminous coal mine dusts.

In our present experiments airborne dusts from an anthracite coal mine and a bituminous coal mine have been used. These have much higher ash contents (mainly kaolin and mica) than the coal dusts used by Belt and King. They were mixed with $10 \%$ and $30 \%$ of commercial quartz of known pathogenicity in order to determine if variable amounts of quartz give variable degrees of fibrosis in the presence of these large amounts of airborne mine dusts ; whether airborne dust has any modifying effect on the quartz; and, if so, whether there is a difference between the anthracite and bituminous coal in this respect.

\section{Minerals and Materials}

The ash content of the anthracite mine dust $\left(400^{\circ} \mathrm{C}\right.$.) was $19 \cdot 2 \%$, and that of the bituminous mine dust was $25.4 \%$. The latter was diluted with sufficient clean bituminous coal of very low ash content (from the same mine) to make the ash about $20 \%$. The particle sizes of the two dusts were determined (Table 1). Although these were airborne dusts only about $33 \%$ (by mass) of the anthracite and $20 \%$ of the bituminous were suffi-

TABLE 1

SIZE DISTRIBUTION OF COAL MINE DUSTS

\begin{tabular}{|c|c|c|c|c|}
\hline \multirow{2}{*}{$\begin{array}{r}\text { Size } \\
(\mu)\end{array}$} & \multicolumn{2}{|c|}{$\begin{array}{l}\text { Percentage of } \\
\text { Anthracite } \\
\text { Particles }\end{array}$} & \multicolumn{2}{|c|}{$\begin{array}{l}\text { Percentage of } \\
\text { Bituminous } \\
\text { Particles }\end{array}$} \\
\hline & $\begin{array}{c}\text { By } \\
\text { Number }\end{array}$ & $\begin{array}{l}\text { By } \\
\text { Mass }\end{array}$ & $\begin{array}{c}\text { By } \\
\text { Number }\end{array}$ & $\begin{array}{c}\text { By } \\
\text { Mass }\end{array}$ \\
\hline 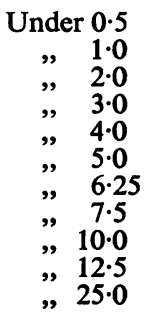 & $\begin{array}{r}20 \cdot 5 \\
42.5 \\
60.5 \\
73 \cdot 5 \\
80.5 \\
86.0 \\
91 \cdot 5 \\
94.5 \\
97 \cdot 0 \\
99 \cdot 0 \\
100.0\end{array}$ & $\begin{array}{c}0.002 \\
0.1 \\
0.5 \\
1.9 \\
4.1 \\
7.6 \\
14.6 \\
21.4 \\
33.3 \\
53.4 \\
100.0\end{array}$ & $\begin{array}{r}30.0 \\
64 \cdot 5 \\
78 \cdot 0 \\
86.0 \\
89.0 \\
93.0 \\
95 \cdot 0 \\
96.5 \\
97 \cdot 5 \\
99.0 \\
100 \cdot 0\end{array}$ & $\begin{array}{c}0.004 \\
0.14 \\
0.6 \\
1 \cdot 7 \\
2.9 \\
6 \cdot 2 \\
9.5 \\
13.9 \\
20 \cdot 1 \\
39 \cdot 6 \\
100.0\end{array}$ \\
\hline
\end{tabular}


ciently small to be likely to enter the lungs of miners by inhalation. The upper limit of size of respirable dust for the rat is not known ; in these experiments the dusts were introduced directly into the lung by injection.

\section{Experimental Procedure}

The animal experiments were conducted along the lines described by Kettle and Hilton (1932) and as modified by Belt and King (1945) and Ray, King, and Harrison (1951a, b). Suspensions in normal saline of mine dusts and quartz were made. These were sterilized by heating on a water bath at $100^{\circ} \mathrm{C}$. for 15 minutes. The rats were lightly anaesthetized with ether, and each rat was given $1.5 \mathrm{ml}$. of the suspension intratracheally by means of a hypodermic needle. Each $1.5 \mathrm{ml}$. of suspension contained $70 \mathrm{mg}$. of mine dust (anthracite or bituminous) plus $30 \mathrm{mg}$. of quartz, or $90 \mathrm{mg}$. mine dust plus $10 \mathrm{mg}$. of quartz. Eighteen rats were used in each experiment. The rats were killed (or died) at different intervals up to 380 days, and the progress of the lesions was studied. The lungs of some rats were lost through cannibalism.

Pathological Technique.-The lungs were removed after insufflation of the trachea-with formol saline.

TABLE 2

ASSESSMENT OF FIBROSIS IN LUNGS OF RATS

Anthracite Airborne Dust Anthracite Airborne Dust (90 mg. plus quartz $10 \mathrm{mg}$.) (70 mg. plus quartz $30 \mathrm{mg}$.)

\begin{tabular}{|c|c|c|c|}
\hline $\begin{array}{l}\text { Days of } \\
\text { Survival }\end{array}$ & $\begin{array}{l}\text { Reticulin } \\
\text { Fibrosis } \\
\text { (Grade) }\end{array}$ & $\begin{array}{l}\text { Days of } \\
\text { Survival }\end{array}$ & $\begin{array}{l}\text { Reticulin } \\
\text { Fibrosis } \\
\text { (Grade) }\end{array}$ \\
\hline $\begin{array}{r}33 \\
68 \\
87 \\
108 \\
124 \\
129 \\
139 \\
170 \\
171 \\
200 \\
205 \\
222 \\
245 \\
264 \\
296 \\
380\end{array}$ & $\begin{array}{l}0 \\
1 \\
1 \\
1 \\
1 \\
1 \\
1 \\
2 \\
2 \\
2 \\
2 \\
3 \\
3 \\
-3 \\
3 \\
3\end{array}$ & $\begin{array}{r}8 \\
39 \\
111 \\
112 \\
- \\
163 \\
169 \\
177 \\
219 \\
250 \\
301 \\
301 \\
329 \\
380\end{array}$ & $\begin{array}{l}0 \\
0 \\
2 \\
2 \\
- \\
3 \\
3 \\
4 \\
4 \\
4 \\
4 \\
4 \\
4 \\
4\end{array}$ \\
\hline \multicolumn{2}{|c|}{$\begin{array}{l}\text { Bituminous Airborne } \\
\text { Dust } \\
\text { (90 mg. plus quartz } 10 \mathrm{mg} .)\end{array}$} & \multicolumn{2}{|c|}{$\begin{array}{l}\text { Bituminous Airborne } \\
\text { Dust } \\
\text { (70 mg. plus quartz } 30 \mathrm{mg} \text {.) }\end{array}$} \\
\hline $\begin{array}{r}-11 \\
17 \\
84 \\
84 \\
152 \\
254 \\
296 \\
379\end{array}$ & $\begin{array}{l}-0 \\
0 \\
1 \\
1 \\
2 \\
3 \\
4(?) \\
3\end{array}$ & $\begin{array}{r}1 \\
11 \\
25 \\
80 \\
112 \\
147 \\
250 \\
330 \\
344\end{array}$ & $\begin{array}{l}0 \\
0 \\
0 \\
2 \\
4 \\
4 \\
4 \\
4 \\
4\end{array}$ \\
\hline
\end{tabular}

Blocks for section were taken through the middle of both lungs, and sections were stained with haematoxylin and eosin and by Gordon and Sweets' (1936) silver impregnation method for reticulin.

\section{Results}

Anthracite Airborne Dust (90 mg.) plus Quartz (10 mg.).-No fibrosis was noticed on the 33rd day. Grade 1 was seen from the 68th day till the 139th day. Grade 2 fibrosis was present from the 170 th day till the 205th day, and grade 3 from the 222nd day till the 380 th day.

Anthracite Airborne Dust (70 mg.) plus Quartz (30 mg.).-Grade 2 fibrosis was seen on the 111th day. This changed to grade 3 on the 163rd day, and to grade 4 on the 177 th day, and remained so till 380 days.

Bituminous Airborne Dust (90 mg.) plus Quartz (10 mg.).-No reticulin fibrosis was noticed till the 84th day, when the dust was found enmeshed in nodules of loose reticulin fibrils of grade 1 . On the 152 nd day the fibrosis had changed to grade 2 . Grade 3 fibrosis was found on the 254th day and on the 379th day. One section at the 296th day showed one or two nodules bordering on grade 4 .

Bituminous Airborne Dust (70 mg.) plus Quartz (30 mg.).-On the 80 th day grade 2 fibrosis was noticed. Grade 4 fibrosis was present on the 112th day. Lungs examined at intervals from this day to the 344 th day showed grade 4 fibrosis.

\section{Discussion}

These experiments with artificial mixtures provide a method of studying the modifying action of airborne mine dusts on different amounts of quartz of known pathogenicity. Belt and King (1945) produced grade 4 fibrosis in 365 days with $100 \mathrm{mg}$. doses of airborne mine dusts from different sources mixed with $20 \%$ or more of quartz. In the present experiment we have found that when $10 \mathrm{mg}$. of quartz was mixed with $90 \mathrm{mg}$. of either anthracite or bituminous coal the maximum effect obtained was grade 3 fibrosis after 380 days. When the amount of quartz was increased to $30 \mathrm{mg}$. mixed with $70 \mathrm{mg}$. of coal dust grade 4 fibrosis was produced as early as 112 days with bituminous, and 177 with anthracite dust, and remained so up to 380 days. The more free silica in the dust, the more severe was the pathogenicity of the dust, and no noticeable inhibitory effect of the mine dusts was demonstrated. It is interesting to compare these results with those obtained with 10 or $30 \mathrm{mg}$. of quartz alone (Ray, King, and Harrison, page 63). With $10 \mathrm{mg}$. of quartz the fibrosis produced was 
grade 2 up to the 316th day, and with $30 \mathrm{mg}$. grade 3 fibrosis up to 283 days and grade 4 in 350 days. It therefore seems that these mine dusts had very little, if any, modifying or inhibitory action on quartz; rather they seem to have enhanced the action of the quartz, probably by preventing its elimination from the lung parenchyma. This is borne out by our experiments with $2 \mathrm{mg}$. of silica alone and with $98 \mathrm{mg}$. of pure coal plus $2 \mathrm{mg}$. of silica (Ray, King, and Harrison, page 70), where $2 \mathrm{mg}$. of silica alone was completely eliminated from the lung and produced fibrosis only in the hilar gland, whereas when the same amount was mixed with coal it produced grade 3 fibrosis in the lung parenchyma.

\section{Summary}

Tissue reactions in the lungs of rats to artificial mixtures of quartz (10 and $30 \mathrm{mg}$.) with airborne dusts $(90$ and $70 \mathrm{mg}$.) from an anthracite and a bituminous coal mine have been studied.

The airborne dusts contained about $20 \%$ of ash, mainly kaolin and mica. They might have been expected to modify the action of the quartz, and perhaps to different degrees for the anthracite and bituminous.

No difference was observed between the quartzanthracite mixture and the quartz-bituminous mixture at either level of added quartz. No inhibitory effect on the action of the quartz by the mine dusts was found: rather more, than less, fibrous reaction occurred than might have been expected from the amounts of quartz used.

We are grateful to the Medical Research Council for a grant to defray the expenses of this investigation. Miss V. Pash, Mr. W. Weedon, and Mr. B. C. S. Hollands rendered valuable technical assistance. Mr. H. H. Watson kindly obtained for us the specimens of airborne mine dust.

\section{REFERENCES}

Belt, T. H., and King, E. J. (1945). Spec. Rep. Ser. med. Res. Coun. Lond., No. 250, p. 29.

Gordon, H., and Sweets, H. H. Jr. (1936). Amer. J. Path., 12, 545. Kettle, E. H., and Hilton, R. (1932). Lancet, 1, 1190. 